\title{
Geotechnical Properties of Some Coal Fly Ash Stabilized Southwestern Nigeria Lateritic Soils
}

\author{
Emmanuel Akintunde Okunade (Corresponding author) \\ Dept. of Civil Engineering, University of Ado-Ekiti \\ P.M.B. 5363, Ado-Ekiti, Nigeria \\ Tel: 234-803-503-6494Ｅ-mail: eaokunade@yahoo.com
}

\begin{abstract}
This study on stabilization of tropical lateritic soils using self-cementing coal fly ash evaluated the effects of the addition of self-cementing coal fly ash on the engineering properties of three lateritic soils from southwestern Nigeria. The engineering properties investigated were those normally involved in highway design and construction. Increasing percentages (by weight of dry soil) of coal fly ash, ranging from $0 \%$ through $15 \%$ in $2.5 \%$ increments, were added and the geotechnical properties assessed. It was observed, for all the soils, that increasing coal fly ash contents brought about increasing improvements in the plasticity and mechanical properties of the soils. When comparing the average value of the properties at $0 \%$ coal ash content to their average values at $12.5 \%$ coal ash content, there was a reduction in the liquid limits (from $39.0 \%$ to $33.3 \%$ ), a reduction in the plasticity indices (from $15.3 \%$ to $9.3 \%$ ), a reduction in the optimum moisture contents (from $15.8 \%$ to $9.7 \%$ ) accompanied by an increase in the maximum dry densities (from 1920 to $2180 \mathrm{~kg} / \mathrm{m}^{3}$ ), and an increase in the unsoaked CBR values (from $20.0 \%$ to $53.0 \%$ ). For the stabilization of lateritic soils with coal fly ash, a coal fly ash of $12.5 \%$ by weight of dry soil was recommended because the improvements in the soil's properties tapered off at about that percentage of coal ash content.
\end{abstract}

Keywords: Soil stabilization, Coal fly ash, Lateritic soils, Self-cementing

\section{Introduction}

According to the American Coal Ash Association (2008), coal combustion products (CCP) are the materials produced when we burn coal to generate electricity. They include fly ash, bottom ash, boiler slag, flue gas desulfurization (FGD) gypsum, and other power plant byproducts. The quantities of these by-products produced annually are enormous. For example, in the USA, up to a total of 111 million metric tons of these products were produced in 2004, of which fly ash 64.3, bottom ash 25.5, boiler slag 2.0, and FGD gypsum 28.5 million metric tons (US Geological Survey, 2006). In 2007, the total had increased to 131 million metric tons (American Coal Ash Association Educational Foundation, 2010). In China, about 375 million tons of coal ash (fly ash and bottom ash) were produced in 2009 (Greenpeace, 2010). This trend is set to continue, because coal-fired power plants continue to be a major contribution to electricity production in many countries. And with present technology, there are no other large sources of energy on the horizon that would enable immediate ramp down of coal usage. Barnes and Sear (2004) gave the contribution of coal-fired electricity generation in Poland as 94.8\%, South Africa 93.0\%, India 78.3\%, Australia 76.9\%, China 76.2\%, Czech Rep 66.7\%, Greece 62.3\% Germany 52.0\%, USA $49.9 \%$, Denmark $47.3 \%$, and in the UK $32.9 \%$. In Nigeria, because of the poor performance and development of hydro and thermal power plants, coal-based power plants are, and will continue to be, the backbone of Nigeria's energy engine. They currently account for about $54 \%$ of installed capacity of utilities, and projections by the (Nigerian) Energy Commission indicate that coal will fuel the power sector for at least the next three decades (Arizona-Ogwu, 2008; Sambo, 2008).

The storage of these coal combustion by-products has constituted a serious economic problem. For example, Greenpeace (2010), reported that in terms of volume, the coal ash production in China for 2009 amounts to 424 million cubic meters a year, enough to fill a standard swimming pool every two and a half minutes. It has also been a major hazard to the environment, as evidenced by the Kingston Fossil Plant coal fly ash slurry spill in Tennessee, USA in December 2008, in which about 4.2 million $\mathrm{m}^{3}$ of coal fly ash slurry was released (Dewan, 2008), and similar incidents. To alleviate these problems, substantial parts of these by-products have been used in various applications, including, amongst others, the following: as fill material for structural applications and embankments; as aggregate in road bases, sub-bases, and pavements; as aggregate and raw material in concrete products and grout; as mineral filler in asphalt; as feed stock in the production of cement; and as an admixture in 
soil modification and/or stabilization.

Coal fly ash has been immensely and widely used in this last application, for different kinds of soils, due mainly to its pozzolanic properties. Coal fly ash is an artificial pozzolan, i.e. a siliceous or siliceous/aluminous material that, when mixed with lime and water, forms a cementitious compound. Coal fly ash is the best known, and one of the most commonly used, pozzolans in the world.

Coal fly ash is a by-product of coal fired electric power plants. It is the finely-divided and powdery coal combustion product collected by electrostatic precipitators or baghouses from the flue gases (Fly Ash Resource Center, 2010). Two classes of fly ash are defined by ASTM Standard C618 - 08a (2008). These are Class F fly ash and Class $\mathrm{C}$ fly ash. The chief difference between these classes is the amount of calcium, silica, alumina, and iron content in the ash. The chemical properties of the fly ash are largely influenced by the chemical content of the coal burned, which in turn depends on the type of coal, which could be anthracite, bituminous or sub-bituminous coal, or lignite. Class F fly ash is produced from the burning of anthracite or bituminous coal, and is generally low in lime, usually under 15 percent, and contains a greater combination of silica, alumina and iron (greater than 70 percent) than Class $\mathrm{C}$ fly ash. It is siliceous and typically pozzolanic. Class $\mathrm{C}$ fly ash is produced from lignite or sub-bituminous coal. These types of coal produce an ash with higher lime $(\mathrm{CaO})$ content (from 15 to 30 percent), which makes it calcareous and gives it some unique self-cementing characteristics. Class $\mathrm{C}$ fly ash therefore possesses latent hydraulic properties in addition to its pozzolanic properties, and is therefore especially useful in soil stabilization since it may not require the addition of lime.

Lateritic soils are widespread around the world, especially in the tropics. Because of their non-swelling characteristics, they are often used as imported fill material for the prepared subgrade in different kinds of road projects. In fact, in low-cost road projects in many developing countries such as Nigeria, in many instances lateritic soils are employed in the base layer, then topped with a single or double surface dressing. To enhance the durability of such roads, the lateritic soils are often stabilized, traditionally with cement, lime or bitumen, and these in combination with different admixtures (such as coal fly ash, rice husk ash, and many other industrial and agricultural by-products). However, stabilization with only coal fly ash has not been much practiced. Nigerian coal has been widely ranked as being sub-bituminous (mainly) and lignite (Akande et.al., 1992; Methane to Markets, 2005; EIA, 2006; Adeleke et al., 2007; Sambo, 2008), indicating the class of fly ash derived from them to be Class C. Because it possesses self-cementing properties apart from its pozzolanic properties, and because of its availability and low cost, stabilization with only Class $\mathrm{C}$ fly ash is worth investigating.

Much work has been done world-wide on the stabilization of soil with coal fly ash (Brown et al., 1991; Indraratna et al., 1991;Beeghly, 2003; Mackiewicz and Ferguson, 2005; White et al., 2005; Eskioglou and Oikonomou, 2008; Sear, 2008; Brooks, 2009; Li et al., 2009; Rifa'i et al., 2009). However, investigations involving tropical lateritic soils are indeed few. This study aimed to address this by investigating the effect of coal fly ash stabilization on the geotechnical properties (especially those concerned with highway design and construction) of treated lateritic soils and proffering recommendations.

\section{Materials and Methods}

This study was conducted on soil samples taken from three different locations from three different states within the southwestern part of Nigeria. The samples were collected at a depth of about 1.5 meters below the ground surface Soil A sample was collected at km. 6+700 along the Ado-Iworoko Road in Ekiti State, Soil B sample was collected at km. 15+000 along the in Akure-Ondo Road in Ondo State, while Soil C sample was collected at km. $3+400$ along the Sagamu-Ikenne Road in Ogun State. The locations all lie between latitudes $6^{\circ} 50^{\prime} \mathrm{N}$ and $7^{\circ} 40^{\prime} \mathrm{N}$ and longitudes $3^{\circ} 40^{\prime} \mathrm{E}$ and $5^{\circ} 20^{\prime} \mathrm{E}$ (see Figure 1). Geologically, the locations fall within the basement complex of southwestern Nigeria. The laterite crust over this area is a thin layer of ironstone, from about 1 to 6 meters thick, deposited within the Quaternary age (Durotoye, 1983).

After collection, the soil samples were spread out in the laboratory for two weeks for air-drying at room temperature, after which the clods were broken down and the samples well pulverized. Thereafter, employing standard procedures, the samples were tested for their classification and index properties, as well as their consistency properties. The results are shown in Table 1. The coal fly ash obtained was grayish in colour and powdery in texture. From its particle size distribution analysis, it was found that $92 \%$ of its weight passes through sieve No $200(75 \mu \mathrm{m})$, something that indicates the hydraulic and pozzolanic properties.

Afterwards, the self-cementing coal fly ash was added at rates of $2.5 \%, 5.0 \%, 7.5 \%, 10.0 \%, 12.5 \%$ and $15.0 \%$ (by dry weight of soil) to the different soils and their consistency properties and moisture-density relationships investigated. Furthermore, samples were prepared for the unsoaked California Bearing Ratio (CBR) tests which 
were carried out after curing for three days.

\section{Results and Discussion}

In most systems of soil classification, the silt and clay grain sizes comprise the fraction passing the $0.075 \mathrm{~mm}$ sieve size, while the sand fraction comprises grains passing the $2.36 \mathrm{~mm}$ sieve size and retained on the $0.075 \mathrm{~mm}$ sieve size. It is evident therefore, from Table 1, that though the sand fraction is predominant in the particle size distribution of all the soils sampled in the study, the clay fraction is also significant (greater than $30 \%$ ). With the plastic limits relatively high (between 37 and $42 \%$ ) and the plasticity indices from 14 to $17 \%$, the soils are classified as A-6, A-7-5 and A-2-6, respectively, according to the AASHTO classification system. According to the Unified Soil Classification system, Soils A and C belong to SC group (silty sand with medium plasticity), while Soil B belongs to the SM group (clayey sand with medium plasticity). Soils A and C plot below the A-line in the Casagrande plasticity chart, while Soil C plots above it. According to both classification systems, the general rating of all the soils as a road foundation was "fair to poor", suggesting that some modification through stabilization would be necessary.

The results of the addition of varying contents by weight of coal fly ash to the different soil samples are presented in Tables $2 \mathrm{a}$ to $2 \mathrm{c}$, and the average results in Table $2 \mathrm{~d}$.

It was observed that increasing the percentages of coal fly ash content from 0 to $15 \%$ resulted in marginal decreases in the liquid limits (from an average of about $39.0 \%$ to an average of about $33.3 \%$ when comparing the values at $0 \%$ and $12.5 \%$ coal fly ash contents) and marginal increases in the plastic limits of the soils. With this, there was a noticeable decrease in the plasticity indices (from an average of about $15.3 \%$ to an average of about $9.3 \%$ when comparing the values at $0 \%$ and $12.5 \%$ coal fly ash contents).

It was also observed that with increasing coal fly ash contents, the optimum moisture contents decreased (from an average of about $15.8 \%$ to an average of about $9.7 \%$ when comparing the values at $0 \%$ and $12.5 \%$ coal fly ash contents) while the maximum dry densities increased (from an average of about $1920 \mathrm{~kg} / \mathrm{m}^{3}$ to an average of about $2180 \mathrm{~kg} / \mathrm{m}^{3}$ when comparing the values at $0 \%$ and $12.5 \%$ coal fly ash contents). Similarly, the unsoaked CBR of the different soils increased with increasing coal fly ash content (from an average of about $20.0 \%$ to an average of about $53.3 \%$ when comparing the values at $0 \%$ and $12.5 \%$ coal fly ash contents).

These improvement in the natural and mechanical characteristics of lateritic soil stabilized with coal fly ash is in line with those observed in other types of soil stabilized with coal fly ash (Brown et al., 1991; Beeghly, 2003; Mackiewicz and Ferguson, 2005; White et al., 2005; Eskioglou and Oikonomou, 2008; Brooks, 2009; Li et al., 2009; Rifa'i et al., 2009).

For the plasticity indices, it was observed that the values dropped sharply from $0 \%$ content until about $10 \%$ to $12.5 \%$ content when the value seemed to remain constant. The final value of the plasticity indices (around 9 to $10 \%$ ) from the initial high values (between 14 and 17\%) has placed the modified soils, according to AASHTO criteria, as suitable materials for subgrade and base course construction.

Similarly, the rate of decrease in the values of the optimum moisture content and increase in the maximum dry densities and CBR values seemed to peter out around coal fly ash contents of $12.5 \%$. With all the above, it can be reasonably concluded that an overall optimum coal fly ash content by weight for the stabilization of lateritic soils is $12.5 \%$. This is comparable to values recommended by other investigators, though for different soil types. White et al. (2005) recommended addition rates of $10 \%$ to $20 \%$ (by dry weight of soil) for Iowa self-cementing fly ashes for effective stabilization of fine-grained Iowa soils for earthwork and paving operations. Mackiewicz and Ferguson (2005) stated that most fly ash stabilization applications require fly ash contents ranging from 12 to $15 \%$ (dry weight basis). Eskioglou and Oikonomou (2008) opined that, when sand-gravels are stabilized beyond $10 \%$ of fly ash, the strength is not considerably increased and stabilization has nothing more to offer.

\section{Conclusion and Recommendations}

From this study, the following conclusions and recommendations can be drawn:

- For lateritic soils, addition of about $12.5 \%$ (by dry weight of soil) of self-cementing coal fly ash provides the most effective stabilization when all the properties are considered together.

- The mixture of coal fly ash with lateritic soils improves the plasticity and mechanical properties of the soil, as expressed by a reduction in the liquid limit and the plasticity index.

- With regard to the influence of self-cementing fly ash on density and compaction, test results show that fly ash increases the compacted dry density and reduces the optimum moisture content of lateritic soils.

- Coal fly ash stabilization increases the CBR of lateritic soils. For the soils tested, the CBR values 
increased from about $20 \%$ to about $56 \%$ for $12.5 \%$ coal fly ash addition.

- Usage of fly ash for stabilization offers an effective way of reducing the burden of storage and disposal of the waste by-products of coal combustion and the attendant environmental and health hazards.

- Economically, coal fly ash stabilization is much cheaper than stabilization with the conventional materials. Mackiewicz and Ferguson (2005) stated that fly ash treatment is generally more economical than the lime and cement alternatives even when larger quantities of ash have to be added to achieve the stabilization required.

\section{References}

Adeleke, A. O., Makan, R. S., \& Ibitoye, S. A. (2007). Gray-king assay characterisation of Nigerian Enugu and Polish Bellview coals for co-carbonisation. J. Applied Sci., 7: 455-458. doi: $10.3923 /$ jas.2007.455.458.

Akande, S. O., Hoffknecht, A., \& Erdtmann, B. D. (1992, April). Rank and petrographic composition of selected upper cretaceous and tertiary coals of Southern Nigeria, International Journal of Coal Geology, 20(3-4), 209-224.

doi: 10.1016/0166-5162(92)90014-N.

American Coal Ash Association. (2008). What are Coal Combustion Products? Retrieved August 20, 2010, from http://acaa.affiniscape.com/displaycommon.cfm? an=8

American Coal Ash Association Educational Foundation. (2010). Coal Ash Facts. Retrieved August 28, 2010, from http://www.coalashfacts.org/

Arizona-Ogwu, L. C. (2008, July 27). Nigeria and the electricity ordeal: Is coal still viable? Retrieved August 20, 2010, from http://www.kwenu.com/publications/arizona_ogwu/2008/nigeria_electricity_coal_viable.htm

ASTM Standard C618 - 08a. (2008). Standard specification for coal fly ash and raw or calcined natural pozzolan for use in concrete. ASTM International, West Conshohocken, PA, Retrieved August 20, 2010, from http://www.astm.org/Standards/C618.htm

doi: $10.1520 / \mathrm{C} 0618-08$

Barnes, I., \& Sear, L. (2004, Dec.). Ash utilisation from coal-based power plants, Report No. COAL R274, DTI/Pub. URN 04/1915 Retrieved August 20, 2010, from www.berr.gov.uk/publications/

Beeghly, J. H. (2003). Recent experiences with lime-fly ash stabilization of pavement subgrade soils, base, and recycled asphalt. Presented at the 2003 International Ash Utilization Symposium, Univ. of Kentucky, Center for Applied Energy Research, Lexington, KY, Oct. 20-22, 2003, p. 1-18.

Brooks, R. M. (2009). Soil stabilization with flyash and rice husk ash. International Journal of Research and Reviews in Applied Sciences 1(3), 209-217.

Brown, T. H., Brown, M. A., Sorini, S. S., \& Huntington, G. (1991). The use of coal fly ash for soil stabilization. Topical report. University of Wyoming Research Corporation. Retrieved August 16, 2010, from http://www.osti.gov/bridge/servlets/purl/10124960-WzAavi/native/10124960.pdf

Dewan, S. (2008, December 28). Tennssee Ash Flood Larger than initial estimate. The New York Times. Retrieved August 27, 2010, from http://www.nytimes.com/2008/12/27/us/27sludge.html?_r=1

Durotoye, B. (1983): “Geomorphology and Quaternary Deposits of Nigeria," In Ola, S. A. (Ed.), Tropical Soils of Nigeria in Engineering Practice, (pp.1-16). Rotterdam: A. A. Balkema.

EIA (2006). International Energy Annual 2006: World Estimated Recoverable Coal, December 31, 2005 (Million Short Tons). Washington, DC: U.S. Energy Information Administration (EIA). Retrieved August 26, 2010, from http://www.eia.doe.gov/pub/international/iea2006/table82.xls

Eskioglou, P., \& Oikonomou, N. (2008) Protection of environment by the use of fly ash in road construction, Global NEST Journal, 10(1), 108-113

Fly Ash Resource Center. (2010). Coal Combustion Products, Retrieved August 20, 2010, from http://www.rmajko.com/flyash.html

Greenpeace. (2010). The True Cost of Coal: An Investigation into Coal Ash in China. Retrieved August 20, 2010, from http://www.greenpeace.org/raw/content/china/en/press/reports/coal-ash-report -english-2010.pdf

Indraratna, B., Nutalaya, P., \& Kuganenthira, N. (1991). Stabilization of a dispersive soil by blending with fly ash. Quarterly Journal of Engineering Geology and Hydrogeology 24, 275-290 
Li, L., Edil, T. B., \& Benson, C. H. (2009). Mechanical Performance of Pavement Geomaterials Stabilized with Fly Ash in Field Applications. Coal Combustion and Gasification Products 1, 43-49

doi: 10.4177/CCGP-D-09-00018.1

Mackiewicz, S. M., \& Ferguson, E. G. (2005). Stabilization of soil with self-cementing coal ashes. World of Coal Ash (WOCA), April 11-15, 2005, Lexington, Kentucky, USA. p. 1-7

Methane to Markets. (2005). Nigeria's Country Report on Coal Mine Methane Recovery and Use, presented at the Methane to Markets Regional Workshop, December 2, 2005, Beijing, China.

National Geographic Society (1998). Xpeditions atlas maps: Nigeria. Retrieved October 22, 2010 from http://www.nationalgeographic.com/xpeditions/atlas/nigeri/nigeri-dl.gif

Rifa'i, A., Yasufuku, N., \& Tsuji, K. (2009). Characterization and effective utilization of coal ash as soil stabilization on road application. In C. F. Leung, C. F., Chu, J., \& Shen, R. F. (Eds). Ground Improvement Technologies and Case Histories. Singapore: Research Publishing Services.

doi:10.3850/GI025

Sambo, A. S. (2008). Matching electricity supply with demand in Nigeria. International Association for Energy Economics publication, Fourth Quarter, p. 32-36. Retrieved Sepember 15, 2010 from http://www.iaee.org/en/publications/newsletterdl.aspx?id=56

Sear, L. K. A. (2008). Using coal fly ash in road construction. Proceedings of LJMU 2008 Annual International Conference 20th-21st February 2008, Liverpool, UK. Research And Practical Applications Using Sustainable Construction Materials And Technology In Asphalt And Pavement Engineering.

U.S. Geological Survey, 2006, Coal combustion products statistics, in Kelly, T.D., and Matos, G.R., comps., Historical statistics for mineral and material commodities in the United States: U.S. Geological Survey Data Series 140. Retrieved August 28, 2010, from http://pubs.usgs.gov/ds/2005/140/

White, D. J., Harrington, D., \& Thomas, Z. (2005). Fly ash soil stabilization for non-uniform subgrade soils, Volume I: Engineering properties and construction guidelines. Report No. IHRB Project TR-461; FHWA Project 4. Center for Transportation Research and Education, Iowa State University. Retrieved August 16, 2010, from http://www.intrans.iastate.edu/reports/tr461_vol1.pdf 
Table 1. Physical Properties Of Soil Samples

\begin{tabular}{|c|c|c|c|c|}
\hline \multicolumn{2}{|c|}{ PHYSICAL PROPERTY } & SOILA & SOIL B & SOIL C \\
\hline \multicolumn{2}{|l|}{ Description } & $\begin{array}{l}\text { Red-brown } \\
\text { sandy clay }\end{array}$ & $\begin{array}{l}\text { Red-brown } \\
\text { clayey sand }\end{array}$ & $\begin{array}{l}\text { Light-brown } \\
\text { sandy clay }\end{array}$ \\
\hline \multirow{9}{*}{$\begin{array}{l}\text { Grain size distribution } \\
\text { (percentage passing } \\
\text { sieve sizes): }\end{array}$} & $9.50 \mathrm{~mm}$ & 100.0 & 100.0 & 100.0 \\
\hline & $4.75 \mathrm{~mm}$ & 95.3 & 95.2 & 98.1 \\
\hline & $2.36 \mathrm{~mm}$ & 93.3 & 93.4 & 94.0 \\
\hline & $1.18 \mathrm{~mm}$ & 90.0 & 88.4 & 85.4 \\
\hline & $0.600 \mathrm{~mm}$ & 79.1 & 80.1 & 76.2 \\
\hline & $0.425 \mathrm{~mm}$ & 68.6 & 70.2 & 62.1 \\
\hline & $0.300 \mathrm{~mm}$ & 59.7 & 61.4 & 54.6 \\
\hline & $0.150 \mathrm{~mm}$ & 48.2 & 43.8 & 43.5 \\
\hline & $0.075 \mathrm{~mm}$ & 40.1 & 40.5 & 31.4 \\
\hline \multicolumn{2}{|l|}{ Gravel content, $\%$} & 6.7 & 6.6 & 6.0 \\
\hline \multicolumn{2}{|l|}{ Sand content, \% } & 53.2 & 48.9 & 62.6 \\
\hline \multicolumn{2}{|l|}{ Fines content, $\%$} & 40.1 & 40.5 & 31.4 \\
\hline \multicolumn{2}{|l|}{ Specific Gravity } & 2.70 & 2.86 & 2.88 \\
\hline \multicolumn{2}{|c|}{ Natural Moisture Content, \% } & 18.8 & 20.0 & 15.9 \\
\hline \multicolumn{2}{|l|}{ Liquid Limit, \% } & 38.0 & 42.0 & 37.0 \\
\hline \multicolumn{2}{|l|}{ Plastic Limit, $\%$} & 21.0 & 28.0 & 22.0 \\
\hline \multicolumn{2}{|l|}{ Plasticity Index, \% } & 17.0 & 14.0 & 15.0 \\
\hline \multicolumn{2}{|c|}{ Optimum Moisture Content (Standard Proctor), $\%$} & 18.1 & 14.4 & 15.0 \\
\hline \multicolumn{2}{|c|}{ Maximum Dry Density (Standard Proctor), $\mathrm{kg} / \mathrm{m}^{3}$} & 1840 & 1960 & 1960 \\
\hline \multicolumn{2}{|l|}{ AASHTO Classification } & A-6 & A-7-5 & A-2-6 \\
\hline \multicolumn{2}{|l|}{ Group Index } & 3 & 2 & 1 \\
\hline \multicolumn{2}{|c|}{ Universal Soil Classification } & $\mathrm{SC}$ & MI & $\mathrm{SC}$ \\
\hline
\end{tabular}

Table 2a. Results of the stabilization of soil a with coal fly ash

\begin{tabular}{|l|l|l|l|l|l|l|l|}
\hline \multirow{2}{*}{ SOIL PROPERTY } & \multicolumn{7}{|c|}{ COAL FLY ASH CONTENT, \% BY WEIGHT } \\
\cline { 2 - 8 } & $\mathbf{0}$ & $\mathbf{2 . 5}$ & $\mathbf{5 . 0}$ & $\mathbf{7 . 5}$ & $\mathbf{1 0 . 0}$ & $\mathbf{1 2 . 5}$ & $\mathbf{1 5 . 0}$ \\
\hline Liquid Limit, \% & 38.0 & 37.0 & 35.0 & 36.0 & 32.0 & 37.0 & 31.0 \\
\hline Plastic Limit, \% & 21.0 & 23.0 & 24.0 & 26.0 & 23.0 & 27.0 & 22.0 \\
\hline Plasticity Index, \% & 17.0 & 14.0 & 11.0 & 10.0 & 9.0 & 10.0 & 9.0 \\
\hline $\begin{array}{l}\text { Optimum Moisture Content } \\
\text { (Standard Proctor), \% }\end{array}$ & 18.1 & 16.6 & 15.1 & 11.4 & 10.7 & 10.1 & 10.1 \\
\hline $\begin{array}{l}\text { Maximum Dry Density (Standard } \\
\text { Proctor), kg/m }\end{array}$ & 1840 & 1960 & 1970 & 2080 & 2130 & 2150 & 2180 \\
\hline Unsoaked CBR, \% & 23 & 34 & 38 & 40 & 48 & 56 & 61 \\
\hline
\end{tabular}


Table $2 \mathrm{~b}$. Results of the stabilization of soil $\mathrm{b}$ with coal fly ash

\begin{tabular}{|l|l|l|l|l|l|l|l|}
\hline \multirow{2}{*}{ SOIL PROPERTY } & \multicolumn{7}{|c|}{ COAL FLY ASH CONTENT, \% BY WEIGHT } \\
\cline { 2 - 8 } & $\mathbf{0}$ & $\mathbf{2 . 5}$ & $\mathbf{5 . 0}$ & $\mathbf{7 . 5}$ & $\mathbf{1 0 . 0}$ & $\mathbf{1 2 . 5}$ & $\mathbf{1 5 . 0}$ \\
\hline Liquid Limit, \% & 42.0 & 47.0 & 32.0 & 35.0 & 32.0 & 31.0 & 32.0 \\
\hline Plastic Limit, \% & 28.0 & 34.0 & 19.0 & 24.0 & 22.0 & 22.0 & 24.0 \\
\hline Plasticity Index, \% & 14.0 & 13.0 & 13.0 & 11.0 & 10.0 & 9.0 & 8.0 \\
\hline $\begin{array}{l}\text { Optimum Moisture Content } \\
\text { (Standard Proctor), \% }\end{array}$ & 14.4 & 12.0 & 11.4 & 10.5 & 10.3 & 9.9 & 8.7 \\
\hline $\begin{array}{l}\text { Maximum Dry Density (Standard } \\
\text { Proctor), kg/m }\end{array}$ & 1960 & 2070 & 2120 & 2140 & 2160 & 2190 & 2220 \\
\hline Unsoaked CBR, \% & 18 & 20 & 31 & 32 & 35 & 45 & 48 \\
\hline
\end{tabular}

Table 2c. Results of the stabilization of soil c with coal fly ash

\begin{tabular}{|l|l|l|l|l|l|l|l|}
\hline \multirow{2}{*}{ SOIL PROPERTY } & \multicolumn{7}{|c|}{ COAL FLY ASH CONTENT, \% BY WEIGHT } \\
\cline { 2 - 8 } & $\mathbf{0}$ & $\mathbf{2 . 5}$ & $\mathbf{5 . 0}$ & $\mathbf{7 . 5}$ & $\mathbf{1 0 . 0}$ & $\mathbf{1 2 . 5}$ & $\mathbf{1 5 . 0}$ \\
\hline Liquid Limit, \% & 37.0 & 42.0 & 37.0 & 34.0 & 34.0 & 32.0 & 31.0 \\
\hline Plastic Limit, \% & 22.0 & 28.0 & 25.0 & 23.0 & 24.0 & 23.0 & 22.0 \\
\hline Plasticity Index, \% & 15.0 & 14.0 & 12.0 & 11.0 & 10.0 & 9.0 & 9.0 \\
\hline $\begin{array}{l}\text { Optimum Moisture Content } \\
\text { (Standard Proctor), \% }\end{array}$ & 15.0 & 12.5 & 11.5 & 10.2 & 10.2 & 9.0 & 8.8 \\
\hline $\begin{array}{l}\text { Maximum Dry Density (Standard } \\
\text { Proctor), kg/m }\end{array}$ & 1960 & 2080 & 2120 & 2140 & 2180 & 2190 & 2210 \\
\hline Unsoaked CBR, \% & 19 & 36 & 39 & 41 & 48 & 58 & 57 \\
\hline
\end{tabular}

Table $2 \mathrm{~d}$. Average results of the stabilization of soils a, b and c with coal fly ash

\begin{tabular}{|l|l|l|l|l|l|l|l|}
\hline \multirow{2}{*}{ SOIL PROPERTY } & \multicolumn{7}{|c|}{ COAL FLY ASH CONTENT, \% BY WEIGHT } \\
\cline { 2 - 8 } & $\mathbf{0}$ & $\mathbf{2 . 5}$ & $\mathbf{5 . 0}$ & $\mathbf{7 . 5}$ & $\mathbf{1 0 . 0}$ & $\mathbf{1 2 . 5}$ & $\mathbf{1 5 . 0}$ \\
\hline Liquid Limit, \% & 39.0 & 42.0 & 34.7 & 35.0 & 32.7 & 33.3 & 31.3 \\
\hline Plastic Limit, \% & 23.7 & 28.3 & 22.7 & 24.3 & 23.0 & 24.0 & 22.7 \\
\hline Plasticity Index, \% & 15.3 & 13.7 & 12.0 & 10.7 & 9.7 & 9.3 & 8.7 \\
\hline $\begin{array}{l}\text { Optimum Moisture Content } \\
\text { (Standard Proctor), \% }\end{array}$ & 15.8 & 13.7 & 12.7 & 10.7 & 10.4 & 9.7 & 9.2 \\
\hline $\begin{array}{l}\text { Maximum Dry Density (Standard } \\
\text { Proctor), kg/m }\end{array}$ & 1920.0 & 2036.7 & 2070.0 & 2120.0 & 2156.7 & 2176.7 & 2203.3 \\
\hline Unsoaked CBR, \% & 20.0 & 30.0 & 36.0 & 37.7 & 43.7 & 53.0 & 55.3 \\
\hline
\end{tabular}




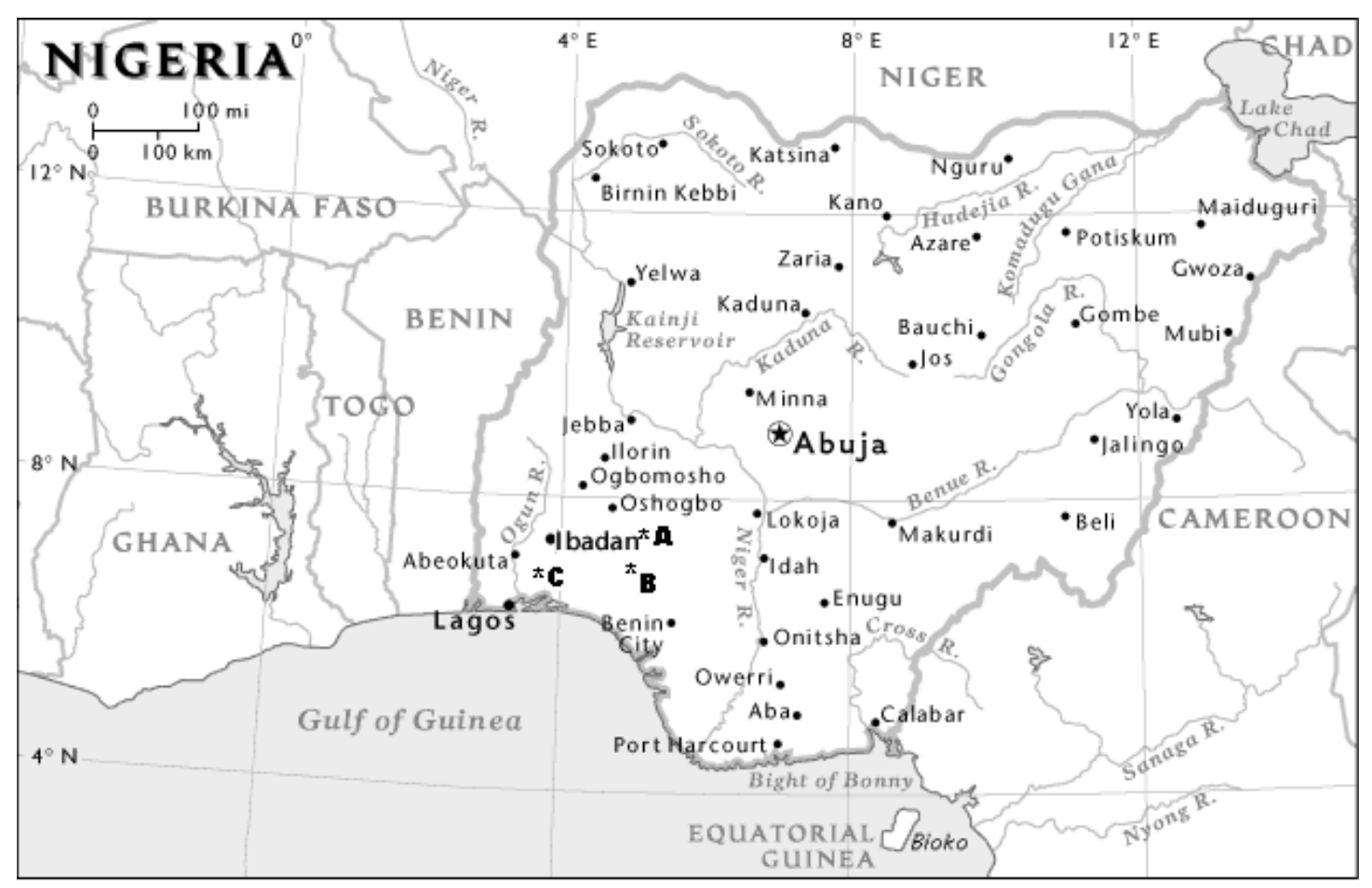

Figure 1. Map showing the locations of soil sample collection (adapted from National Geographic Society, 1998) 